\section{References}

1 Rabbani GH, Greenough III WB, Holmgren J, Lonnroth I. Chlorpromazine reduces fluid loss in cholera. Lancet 1979; ;:410-2.

2 Amin AH, Subbaiah TV, Abbasi DM. Berberine sulfate: antimicrobial activity, bioassay and mode of action. Can $\mathcal{F}$ Microbiol 1969;15:1067-76.

3 Subbaiah TV, Amin AH. Effect of berberine sulfate on Entamoeba histolytica. Nature 1967;215:527-8.

4 Win-Maw. In vitro and in vivo effects of berberine extract of Coptis teeta on Trichomonas vaginalis. Rangoon: Institute of Medicine, 1982. (MMEDSC thesis.)

5 Gupte S. Use of berberine in the treatment of giardiasis. Am $\mathcal{F}$ Dis Child 1975;129:866.

6 Munshi CP, Vaidya PM, Buranturi JJ, Gulati JJ. Kala-azar in Gujarat. $\mathcal{F}$ Indian Med Assoc 1972;59:287-93.

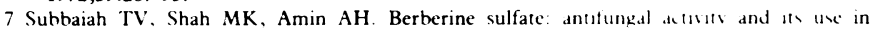
chemotherapy. Proceedings of the All Indian Microbiological (imfereme. Harvana: All Indian chemotherapy. Proceedings of the

8 Akhter $M H$, Aabir $M$, Bhide NK. Anti-inflammatory effect of berberine in rats injected locally with cholera toxin. Indian $\mathcal{F}$ Med Res 1977;65:133-41.
winter

9 Sabir M, Akhter MH, Bhide NK. Antagonism of cholera toxin by berberine in the gastrointestinal tract of adult rats. Indian $\mathcal{F}$ Med Res 1977;65:305-13.

10 Swabb EA, Tai YH, Jordan L. Reversal of cholera toxin-induced secretion in rat ileum by luminal berberine. Am I Physiol 1981;241(3):G248-52.

11 Tai YH, Feser JF, Marnane WG, Desjeux JF. Anti-secretory effect of berberine in rat ileum. Am $\mathcal{f}$ Physiol 1981;241(3):G252-8.
12 Sack RB, Froelich JL. Berberine inhibits intestinal secretory response of $\mathrm{V}$ cholerae and $\mathrm{E}$ coli enterotoxins. Infect Immun 1982;35:471-5.

3 Lahiri SC, Dutta NK. Berberine and chloramphenicol in the treatment of cholera and severe diarrhoea. J Indian Med Assoc 1967;48:1-11.

14 Bhakat MP, Nandi N, Pal HK, Khan BS. Therapeutic trial of berberine sulphate in non-specific gastroenteritis. Indian Medical fournal 1974;68:19-23.

15 Kamath SA. Clinical trial with berberine hydrochloride for the control of diarrhoea in acute gastroenteritis. F Assoc Physicians India 1967;15:55-9.

16 Deshpande PR. Trial with berberine tannate for diarrhoea in children. Bhurat Medical foumal $1969 ; 1: 28-32$

17 Desai AB, Shah KM, Shah DM. Berberine in the treatment of diarrhoea. Indian Pediatr 1971;8:462-5.

18 Sharma R, Joshi CK, Goyal RK. Berberine tannate in acute diarrhoea. Indian Pediatr 1970;7:496-501.

19 Nair S, Modak MJ, Venkatraman A. Vibriostatic action of berberine. Indian fournal of Patholog and Bacteriology 1967;10:389.

20 Greenough WB, Gordon RS Jr, Rosenberg IS, et al. Tetracycline in the treatment of cholera. Lancet 1964; ;:355-7.

21 Akhter MH, Sabir M, Bhide NK. Possible mechanism of antidiarrheal effect of berberine. Indian J Med Res 1979;70:233-41.

(Accepted 30 August 1985)

\title{
Sustained release choline theophyllinate in nocturnal asthma
}

\author{
G B RHIND, J J CONNAUGHTON, J McFIE, N J DOUGLAS, D C FLENLEY
}

\begin{abstract}
Nocturnal wheeze is common in patients with asthma, and slow release theophyllines may reduce symptoms. As theophyllines are stimulants of the central nervous system the effect of 10 days' twice daily treatment with sustained release choline theophyllinate or placebo on symptoms, overnight bronchoconstriction, nocturnal oxygen saturation, and quality of sleep were studied in a double blind crossover study in nine stable patients with nocturnal asthma (five men, four women, age range 23-64 years; forced expiratory volume in one second $\left(\mathrm{FEV}_{1}\right)$ 0.85-3.8 1; vital capacity $1 \cdot 95-6 \cdot 11)$. When treated with the active drug all patients had plasma theophylline concentrations of at least $28 \mathrm{mmol} / \mathrm{l}(5$ $\mu \mathrm{g} / \mathrm{ml}$ ) (peak plasma theophylline concentrations $50-144 \mathrm{mmol} / \mathrm{l}$ $(9-26 \mu \mathrm{g} / \mathrm{ml}))$. Morning $\mathrm{FEV}_{1}$ was higher when treated with sustained release choline theophyllinate $(2.7$ (SEM 0.3) 1) than placebo $(2 \cdot 1(0.3) 1)(p<0.01)$. Both daytime and nocturnal symptoms were reduced when the patients were treated with sustained release choline theophyllinate and subjective quality of sleep was improved $(p<0.002)$. When treated with the active drug, however, quality of sleep determined by electroencephalography deteriorated with an increase in wakefulness and drowsiness $(p<0.05)$ and a reduction in non-rapid eye movement sleep $(p<0.005)$. Treatment with choline theophyllinate had no effect on either the occurrence or the severity of transient nocturnal hypoxaemic episodes or apnoeas or hypopnoeas.

In conclusion, sustained release choline theophyllinate prevents overnight bronchoconstriction but impairs quality of sleep defined by electroencephalography.
\end{abstract}

\footnotetext{
Department of Respiratory Medicine and Rayne Laboratory, City Hospital, Edinburgh EH10 5SB

G B RHIND, MRCP, research fellow

J J CONNAUGHTON, MRCPI, research fellow

J McFIE, technician

N J DOUGLAS, MD, FRCP, senior lecturer

D C FLENLEY, PHD, FRCP, professor

Correspondence to: Dr Rhind, Rayne Laboratory.
}

\section{Introduction}

Nocturnal and morning wheeze are common symptoms of patients with asthma. These patients have overnight decreases in peak expiratory flow rate or forced expiratory volume in one second $\left(\mathrm{FEV}_{1}\right)$.' Possibly as a result of this bronchoconstriction they sleep less well and become more hypoxaemic during the night than do normal subjects. ${ }^{23}$

Although regular inhaled treatment reduces the overnight fall in peak flow rates in those patients who have taken their treatment "as required," some patients still complain of nocturnal symptoms despite adequate inhaled treatment. As a result of this the therapeutic effect of oral long acting $\beta_{2}$ agonists and theophyllines has been studied, ${ }^{56}$ and sustained release theophylline can improve nocturnal symptoms and the morning decrease in peak flow rates ("morning dip") in such patients. ${ }^{6}$ Preparations of sustained release theophyllines are now used widely to treat nocturnal asthma. Theophylline is also, however, a stimulant of the central nervous system and caffeine, a related derivative of xanthine, interferes with the quality of sleep in normal volunteers. ${ }^{7}$ We therefore determined the effect of sustained release choline theophyllinate on both symptoms and peak expiratory flow rate and also on quality of sleep and nocturnal hypoxaemia in patients with nocturnal asthma.

\section{Patients and methods}

Nine asthmatic patients were studied (table I) in whom the airways obstruction showed an improvement of greater than $15 \%$ in $\mathrm{FEV}_{1}$ with inhaled $\beta_{2}$ agonists and spontaneous variability of more than $20 \%$ in the $\mathrm{FEV}_{1}$ recorded at outpatient clinics during the previous two years. All patients complained of nocturnal wheeze, all were atopic, and none smoked. All were clinically stable, none having had an exacerbation of their asthma during the previous six weeks. Each patient regularly inhaled $\beta_{2}$ agonists, eight inhaled steroids, two inhaled disodium cromoglycate, and three inhaled ipratropium bromide. No patient was taking oral theophyllines, oral $\beta_{2}$ agonists, ketotifen, oral prednisolone, sedatives, hypnotics, or antihistamines. All inhaled treatment was withheld for six hours before the start of recording on the study night. Patients were also asked to avoid drinks containing caffeine (coffee, cola, cocoa, or tea) for six hours before recording as caffeine is a bronchodilator. ${ }^{8}$ Each patient gave written informed consent to enter the study, which was approved by the hospital ethical committee.

A randomised placebo controlled double blind crossover study design was used. The patients received $1272 \mathrm{mg}$ of a sustained release choline 
theophyllinate each day (Sabidal-SR, Zyma, United Kingdom), equivalen to $810 \mathrm{mg}$ of anhydrous theophylline in divided doses $(270 \mathrm{mg}$ theophylline each morning and $540 \mathrm{mg} 12$ hours later), or placebo, given in similarly divided doses by mouth for the 10 days preceding and including the study night. Throughout the study patients kept a daily diary card, scoring both daytime and nocturnal symptoms of wheeze and cough and their subjective quality of sleep. Peak expiratory flow rate was recorded on each morning and evening before the inhalers were used. submental electrodes; ear oxygen saturation (Hewlett Packard 47201A ear oximeter), which was also recorded on a separate recorder (Bryans 28000 , Gould Bryans Instruments) running at $0.5 \mathrm{~mm} / \mathrm{second}$; chest and abdominal movements, measured by induction plethysmograph (Respitrace Inc, New York) and analysed on line by a PDP $11 / 40$ computer; and air flow at nose and mouth, recorded by thermocouples mounted on nasal prongs.

Apnoeas and hypopnoeas were defined as previously described ${ }^{9}{ }^{10}$ and stages of sleep measured by electroencephalography defined by standard

TABLE I-Data on patients studied

\begin{tabular}{|c|c|c|c|c|}
\hline Case No & $\begin{array}{c}\text { Age } \\
\text { (years) }\end{array}$ & $\underset{\text { (I) }}{\mathrm{FEV}_{1}}$ & $\begin{array}{c}\text { Vital } \\
\text { capacity (I) }\end{array}$ & $\begin{array}{l}\text { Inhaler } \\
\text { treatment }\end{array}$ \\
\hline 1 & 56 & 0.8 & $3 \cdot 1$ & $\beta_{2}$ agonist; ipratropium bromide; steroid \\
\hline 2 & 62 & $2 \cdot 5$ & 3.9 & $\beta_{2}$ agonist; ipratropium bromide; steroid \\
\hline 3 & 45 & 3.0 & $4 \cdot 4$ & $\beta_{2}$ agonist; disodium cromoglycate \\
\hline 4 & 28 & $3 \cdot 3$ & $4 \cdot 2$ & $\beta_{2}$ agonist; ipratropium bromide; steroid \\
\hline 5 & 44 & $2 \cdot 4$ & 3.6 & $\beta_{2}$ agonist; steroid \\
\hline 6 & 43 & 1.9 & $2 \cdot 3$ & $\beta_{2}$ agonist; steroid \\
\hline 7 & 24 & $4 \cdot 0$ & $6 \cdot 0$ & $\beta_{2}$ agonist; steroid \\
\hline 8 & 54 & $2 \cdot 0$ & $3 \cdot 1$ & $\beta_{2}$ agonist; steroid \\
\hline 9 & 23 & $3 \cdot 3$ & $3 \cdot 7$ & $\beta_{2}$ agonist; disodium cromoglycate; steroid \\
\hline
\end{tabular}

$\mathrm{FEV}_{1}=$ forced expiratory volume in one second.

TABLE II-Oxygen saturation and episodes of hypopnoea and apnoea when treated with placebo and active drug. Values are means (SEM)

\begin{tabular}{|c|c|c|c|c|c|}
\hline \multirow[b]{2}{*}{$\begin{array}{l}\text { Treatment on } \\
\text { study night }\end{array}$} & \multicolumn{2}{|c|}{ Oxygen saturation (\%) } & \multirow[b]{2}{*}{$\begin{array}{l}\text { No of hypoxaemic } \\
\text { episodes }{ }^{\star} \dagger\end{array}$} & \multirow[b]{2}{*}{$\begin{array}{l}\text { No of episodes } \\
\text { of hypopnoea }\end{array}$} & \multirow[b]{2}{*}{$\begin{array}{l}\text { No of episodes } \\
\text { of apnoea } t\end{array}$} \\
\hline & Awake* & $\begin{array}{l}\text { Asleep (lowest } \\
\text { value) }\end{array}$ & & & \\
\hline $\begin{array}{l}\text { Placebo } \\
\text { Theophylline }\end{array}$ & $\begin{array}{l}96(0.5) \\
96(0.5)\end{array}$ & $\begin{array}{l}89(1 \cdot 2) \\
90(1 \cdot 3)\end{array}$ & $\begin{array}{c}2 \\
2 \cdot 1\end{array}$ & $\begin{array}{l}31(10) \\
37(12)\end{array}$ & $\begin{array}{l}6(2) \\
6(3)\end{array}$ \\
\hline
\end{tabular}

^Differences between treatments not significant.

†Total number for entire study night.

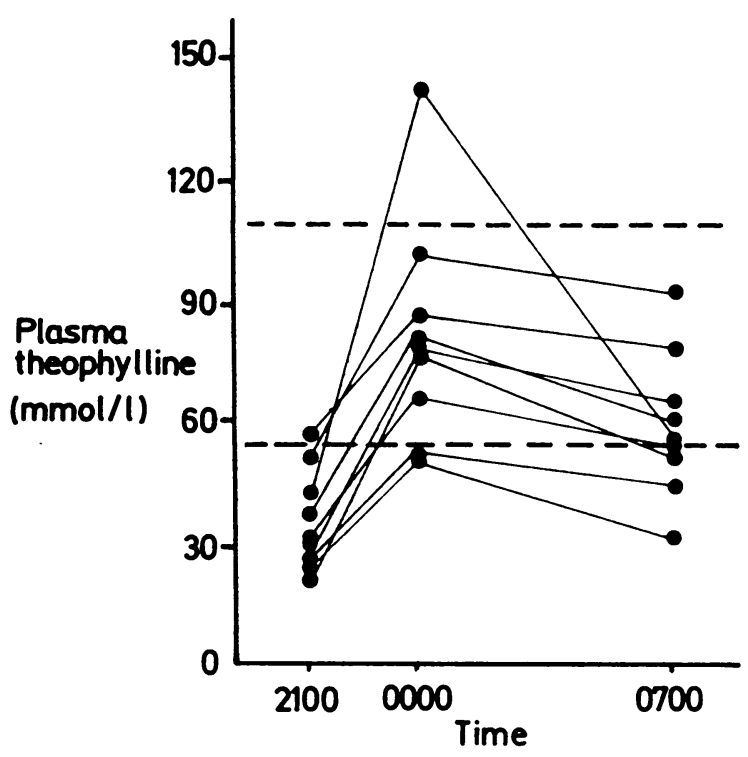

FIG 1-Overnight plasma theophylline concentrations. Area between broken lines is optimal therapeutic range $(56-111 \mathrm{mmol} / \mathrm{l}(10-20$ $\mu \mathrm{g} / \mathrm{ml})$ ).

Conversion: SI to traditional units_Plasma theophylline: $1 \mathrm{mmol} / 1$ $\approx 0 \cdot 18 \mu \mathrm{g} / \mathrm{ml}$.

The patient slept in a quiet darkened room on the final two nights of each part of the study. On each occasion the first of these two nights was used to acclimatise the patient to the equipment and surroundings, and only data from the final night of each part of the study were analysed. The patients FEV $_{1}$ and vital capacity were recorded on the study night before sleep and after final awakening before using their inhalers. The following were recorded on an 18 channel recorder (Neuroscribe 180, SLE), running at 15 $\mathrm{mm} / \mathrm{second}$ throughout each study night: electroencephalogram from two midline frontoparietal electrodes, electro-oculogram from four electrodes placed outside and above the outer canthi, and electromyogram from two criteria. ${ }^{11} \mathrm{~A} 10 \mathrm{ml}$ sample of venous blood was taken on the acclimatisation night between 180 and 240 minutes after the evening dose of choline theophyllinate to assess peak concentrations of theophylline. This sample was taken on the acclimatisation nights to prevent disturbing sleep on the nights of study. On the study night further $10 \mathrm{ml}$ venous blood samples were taken before the evening dose of the drug was taken and at final awakening to measure the trough concentration. The plasma was stored at $-20^{\circ} \mathrm{C}$ until assayed for theophylline and caffeine by high performance liquid chromatography.$^{12}$ Comparisons were made by Student's $t$ test for paired data and by analysis of variance with the method of Newman and Keuls.

\section{Results}

Peak and trough plasma theophylline concentrations (fig 1) show that on the study night (2300-0600) most plasma theophylline concentrations were in the optimal therapeutic range of $56-111 \mathrm{mmol} / 1(10-20 \mu \mathrm{g} / \mathrm{ml})$.

In two patients (cases 3 and 9) although plasma theophylline concentrations were never in this optimal therapeutic range, they were always above 28 $\mathrm{mmol} / \mathrm{l}(5 \mu \mathrm{g} / \mathrm{ml})$. One patient (case 6) had a peak serum concentration of $144 \mathrm{mmol} / \mathrm{l}(26 \mu \mathrm{g} / \mathrm{ml})$ and experienced nausea. Caffeine concentrations ranged from 0 to $12 \mathrm{mmol} / \mathrm{l}(0$ to $2.2 \mu \mathrm{g} / \mathrm{ml})($ mean $4.2 \mathrm{mmol} / \mathrm{l}(0.8 \mu \mathrm{g} / \mathrm{ml})$ ) which were lower than those previously shown to have a therapeutic effect. ${ }^{13}$

On the study nights when receiving placebo all patients showed an overnight decrease in mean (SEM) FEV $(2 \cdot 6(0 \cdot 3) 1$ to $2 \cdot 1(0 \cdot 3) 1 ; \mathrm{p}<0 \cdot 01)$ Choline theophyllinate treatment abolished this nocturnal bronchoconstriction, FEV before sleep being $2 \cdot 8(0 \cdot 3) 1$ and morning FEV $2 \cdot 7(0 \cdot 3) 1$ (NS (fig 2).

Peak expiratory flow rate recorded by the patients at home also showed that treatment with choline theophyllinate abolished overnight bronchoconstriction: when treated with placebo the mean (SEM) evening peak expiratory flow rate was $354(30) \mathrm{l} /$ minute and mean morning peak expiratory flow rate $305(31) 1 /$ minute $(\mathbf{p}<0.01)$, whereas when given the active drug mean evening peak expiratory flow rate was 372 (36) $1 /$ minute and morning peak expiratory flow rate 359 (31) $1 /$ minute (NS). In contrast with the study nights no restriction was placed on the use of the inhalers at home, and the morning values were recorded after the use of $\beta_{2}$ agonist inhalers before sleep. The patients scored their use of inhaled $\beta_{2}$ agonists on a scale of 0 (less than usual), 1 (the same as usual), and 2 (more than usual) and used such inhalers less often when treated with the active drug than with the placebo $(0.7 v 1 \cdot 1 ; \mathbf{p}<0.01)$. The mean daily symptom score, based on a scale 
of 0 (symptom free) to 4 (severe wheeze), showed a significant reduction in daytime wheeze with the sustained release theophylline compared with placebo $(0.7 v 1.2 ; \mathbf{p}<0.01)$, but there was no difference in morning cough $(0.6 v 0.7 ; \mathrm{NS})$. The patients' score for subjective quality of sleep, also based on a score of 0 to $4(0=$ good sleep, $4=$ very poor sleep $)$, was better when treated with active drug than when receiving placebo $(0.7 v 1.4 ; \mathrm{p}<0.002)$.

This subjective improvement in quality of sleep was not confirmed by the sleep stages determined by electroencephalography on the study nights. The mean (SEM) study time was the same when treated with the active drug and the placebo (423 (7) $v 420$ (2) minutes, respectively). There was no difference in the mean time from "lights out" to onset of sleep between the two treatments (32 (9) $v 20$ (6) minutes, respectively; NS). The mean total sleep time (the sum of sleep stages $1,2,3,4$, and rapid eye movement sleep), however, was significantly less when treated with the active drug than with placebo (293 (27) minutes $v 340$ (17) minutes, respectively; $\mathrm{p}<0.05$ ).

The mean (SEM) time from onset of sleep to final awakening (the sleep period time) was not significantly different on the two study nights (388 (11) minutes when treated with active drug; 401 (7) minutes with placebo). When the patients were receiving choline theophyllinate more of the sleep period time was spent in intervening wakefulness and drowsiness (sleep stages 0 and 1 ; mean (SEM) 31 (7)\% when treated with active drug $v 21$ (5)\% with placebo; $<<0.05$ ) and less spent in slow wave sleep (stages 3 and $4 ; 17(2) \%$ with active drug $v 24(4) \%$ with placebo; $p<0.005)$.

There was no difference in the mean (SEM) percentage of time spent in either rapid eye movement sleep (14 (2)\% when treated with active drug $v 16$ (2) $\%$ with placebo; NS) or in stage 2 sleep (37 (3)\% with active drug $v 37(2) \%$ with placebo; NS). Although there was no significant reduction in rapid eye movement sleep when the patients received choline theophyllinate, only one of the nine patients spent more time in rapid eye movement sleep when treated with the active drug. Overall, the mean (SEM) sleep efficiency index (total sleep time/sleep period time) was lower when patients were treated with choline theophyllinate than placebo $(70(7) \% v 81(4) \% ; \mathrm{p}<0.05)$.

The changes in sleep time did not correlate with plasma theophylline concentrations.

The number of times that oxygen saturation fell by more than $4 \%$, the magnitude of these falls, and the number and duration of episodes of apnoeas and hypopnoeas were not significantly different with either treatment (table II).

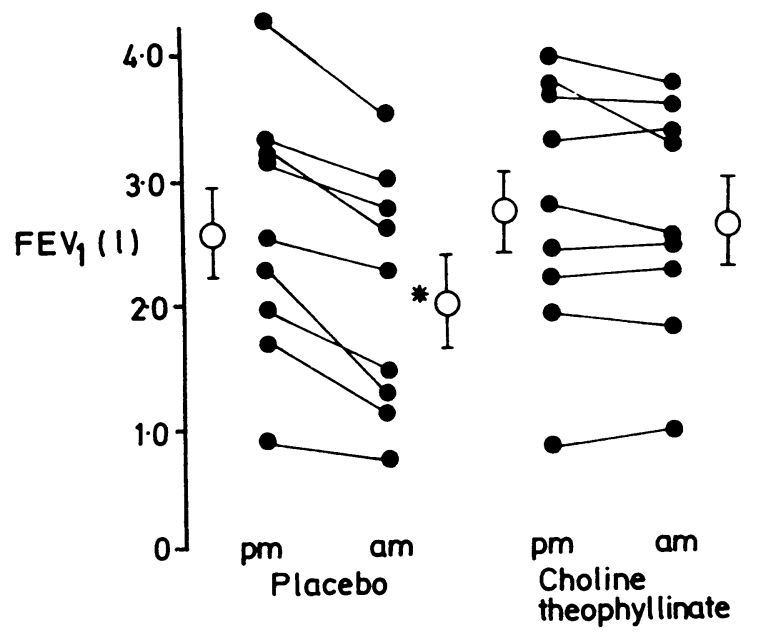

FIG 2-Forced expiratory volume in one second $\left(\mathrm{FEV}_{1}\right)$ before and after sleep after treatment with choline theophyllinate and placebo. ${ }^{\star} \mathrm{p}<0 \cdot 01$.

\section{Discussion}

The results of this double blind placebo controlled crossover study confirm that sustained release choline theophyllinate can abolish overnight bronchoconstriction and improve nocturnal symptoms in patients with nocturnal asthma. ${ }^{6}$ Furthermore, this improvement occurred in asthmatic patients whose nocturnal or morning symptoms remained despite taking regular inhaled treatment.

Asthmatic patients sleep poorly. ${ }^{23}$ Abolition of overnight bronchoconstriction and improvement in nocturnal symptoms might have improved sleep in patients with nocturnal asthma. Our results show, however, that theophylline impaired the quality of sleep, as determined objectively by electroencephalography, by increasing wakefulness and drowsiness and reducing slow wave sleep (stages 3 and 4). Preliminary results have also suggested that theophyllines may reduce the quality of sleep in patients with chronic bronchitis, ${ }^{13}$ but nocturnal symptoms are less troublesome in these patients. The paradoxical improvement in the subjective quality of sleep in asthmatic patients may reflect the patients equating the quality of sleep with reduction in symptoms as they may not recognise or remember brief periods of wakefulness if these are not associated with wheeze. The consequences of the observed disturbances of patterns of sleep are unknown. Gross disruption of sleep impairs the daytime performance, but further studies are required to determine the clinical importance, if any, of the disturbance in sleep that we have described.

A preliminary report by Fleetham et al suggested that nocturnal hypoxaemic episodes were less severe in chronic bronchitic patients who were treated with theophyllines. ${ }^{13}$ We have shown, however, that the mild transient nocturnal hypoxaemic episodes seen in asthmatic patients are not reduced either in number or in magnitude by theophylline, suggesting that these episodes are not caused solely by bronchoconstriction.

Similarly, despite the respiratory stimulant activity of theophylline, apnoeas and hypopnoeas during sleep in these asthmatic patients were not reduced in either number or duration. This is similar to some observations in patients with the sleep apnoea syndrome ${ }^{14}$ though others have found that theophyllines may improve breathing during sleep in such patients. ${ }^{15}$

We conclude that controlled theophylline treatment improves both the symptoms and subjective quality of sleep in asthmatic patients who still experience nocturnal symptoms and a morning reduction in peak expiratory flow rate despite taking regular inhaled treatment with $\beta_{2}$ agonists. Even "therapeutic" serum concentrations of theophylline, however, may result in chronic reduction in quality of sleep as assessed objectively. The improvement in peak expiratory flow rate and the subjective quality of sleep, however, may be more important to the patient than this deterioration in quality of sleep defined by electroencephalography. We suggest that theophylline is an important drug in the treatment of nocturnal asthmatic symptoms but that the long term effects of the disturbances in sleep produced require long term studies as they may be a factor in the behavioural and learning difficulties that have been reported in young patients receiving such treatment. ${ }^{16}$

We thank Mrs C Hoy and Mrs L Sharp for technical help and Zyma UK for its financial support.

\section{References}

1 Lewinsohn HC, Capel LH, Smart J. Changes in forced expiratory volume throughout the day. $\mathrm{Br}$ Med f 1960; i:462-4.

2 Catterall JR, Douglas NJ, Calverley PM, et al. Irregular breathing and hypoxaemia during sleep in chronic stable asthma. Lancet 1982; i:301-4.

3 Montplaisir J, Walsh J, Malo JL. Nocturnal asthma: features of attacks, sleep and breathing patterns. Am Rev Respir Dis 1982;125:18-22.

4 Horn CR, Clark TJH, Cochrane GM. Inhaled therapy reduces morning dips in asthma. Lancet 1984;: $11143-5$

5 Fairfax AJ, McNabb WR, Davies HJ, Spiro SG. Slow release oral salbutamol and aminophylline in nocturnal asthma: relation of overnight changes in lung function and plasma drug levels. Thorax 1980;35:526-30.

6 Barnes PJ, Greening AP, Neville L, Timmers J, Poole GW. Single-dose slow-release aminoBarnes PJ, Greening AP, Neville L, Timmers J, Poole GW. Single-
phylline at night prevents nocturnal asthma. Lancet 1982;i:299-301.

7 Colton T, Gosselin RE, Smith RP. The tolerance of coffee drinkers to caffeine. Clin Pharmacol Ther 1968:9:31-9.

8 Becker AB, Simons KJ, Gillespie CA, Simons FER. The bronchodilator effects and pharmacokinetics of caffeine in asthma. $N$ Engl $\mathcal{H}$ Med 1984;310:743-6.

9 Guilleminault C, van der Hoed J, Mitler MM. Clinical overview of the sleep apnea syndromes. In: Guilleminault C, Dement WC, eds. Sleep apnea syndromes. New York: Alan R Liss, 1978:1. 12.

10 Catterall JR, Calverley PMA, Power JT, Shapiro CM, Douglas NJ, Flenley DC. Ketotifen and nocturnal asthma. Thorax 1983;38:845-8

11 Rechtshaffen A, Kales A. Manual of standardised terminology, techniques and scoring system for sleep stages in human subjects. Bethesda, Maryland: National Institute of Neurological Disease and Blindness, 1968

12 Orcutt JJ, Koyak PP, Gillman JA, Cummins LH. Micro-scale method for theophylline in body fluid by reversed-phase, high-pressure liquid chromatography. Clin Chem 1977;23:599-601.

13 Fleetham JA, Fera T, Edgell G, Jamal K. The effect of theophylline therapy on sleep disorders in COPD patients. Am Rev Respir Dis 1983;127(suppl):A85. (Abstract.)

14 Guilleminault C, Hayes B. Naloxone, theophylline, bromocriptine, and obstructive sleep apnoea.
. Guilleminault C, Hayes B. Naloxone, theophylline, bromocriptine,
Negative results. Bull Eur Physiopathol Respir 1983;19:632-4.

Negative results. Bull Eur Physiopathol Respir 1983;19:632-4.
15 Mayer J, Fuchs E, Penzel T, Peter JH, Schnell H, von Wichert P. Theophylline in patients with Mayer J, Fuchs E, Penzel T, Peter JH, Schnell H, von Wichert P. Theophyll
sleep apnoea syndromes (SAS). Respiration 1984;46(suppl): 158. (Abstract.)

16 Furukawa CT, Shapiro GG, Dutlamel T, Weimer L, Pierson WE, Bierman CW. Learning and behaviour problems associated with theophylline therapy. Lancet 1984;i:621.

(Accepted 25 September 1985) 